\title{
INTEGRATED VALUE CO-CREATION AND AFFECTIVE COMMITMENT IN BANKING INDUSTRY
}

\author{
Nuri WULANDARI ${ }^{1}$, Reza Ashari NASUTION ${ }^{2}$ \\ ${ }^{1}$ Management Studies Program, Indonesia Banking School, Indonesia \\ ${ }^{2}$ School of Business and Management, Bandung Institute of Technology, Indonesia \\ E-mails: ${ }^{1}$ nuri.w.h@ibs.ac.id (corresponding author); ${ }^{2}$ reza@sbm-itb.ac.id
}

Received 06 May 2019; accepted 21 October 2019

\begin{abstract}
Co-creation is a seminal concept in marketing, explained as the engagement between service provider and customer in creating value. This concept has grown into a rich and wide array of studies that have become an area of intense focus in the discipline. Nevertheless, the understanding of the concept, especially in service marketing, is mostly still developing in silos rather than encompassing the entire sphere of value creation. There is a research gap in terms of a measurement scale that is not only integrative, but also encompasses different interaction experiences in the co-creation process. The present research aims to develop a scale measuring integrated value co-creation (IVC) to assess value co-creation in the three spheres of value creation (production, joint and customers' sphere) and try to investigate the impact of IVC on affective commitment (AC). A quantitative survey was administered and a total of 308 respondents in the banking industry have responded. The result confirms the IVC measurement tools with reliability and validity of the construct. It also found a significant and positive relationship between IVC and AC. The study is crucial due to its context in the industry of banking where knowledge on how to innovate becoming the key barrier. The novelty of the study lies in providing empirical evidence of co-creation drive customer commitment. This is achieved through the development of an integrated value co-creation scale that encompasses all spheres of value creation, including customers' direct-indirect interaction and active-passive involvement, in one single construct. The study serves as an important tool during the development stages of co-creation efforts.
\end{abstract}

Keywords: co-creation, marketing, service dominant logic, value creation sphere, banking, affective commitment.

JEL Classification: M31, M10, G20.

\section{Introduction}

Since the publication of the seminal papers by Vargo and Lusch $(2004,2008)$, service-dominant (S-D) logic in marketing has received increasing attention, both practice and academic discussions. One core premise of this logic regards customers as active value creators. It stresses the importance of working together with customers to develop business opportunities, also known as co-creation (Galvagno and Dalli 2014). This important concept has become a tool for creating competitive advantages in marketing (Saarijärvi et al. 2013) and manifested in the removal of any separation between companies and their customers (Prahalad and Ramaswamy 2004). The concept of co-creation has grown to include not only the customers but all business stakeholders (e.g. suppliers, business partners, public organizations, and competitors) (Prahalad and Ramaswamy 2004, Sarkar and Banerjee 2019). However, co-creation is mainly studied in isolation from the wider relational context which result in failing to capture the value of process as integration (Corsaro 2019).

The concept of co-creation has been gaining importance in the service industry, especially in a mature industry that is ripe for innovation such as banking industry. The banking sector is experiencing changing consumer behavior with more demanding client profiles (Oliveira and von Hippel 2011). The industry in the midst of massive restructuring that has caused banks to slash 50,000 jobs worldwide this year alone (Comfort 2019). Jimenez (2019) emphasizes that

Copyright (c) 2019 The Authors. Published by VGTU Press.

This is an Open Access article distributed under the terms of the Creative Commons Attribution License (http://creativecommons.org/licenses/by/4.0/), which permits unrestricted use, distribution, and reproduction in any medium, provided the original author and source are credited.. 
banks need to innovate and respond to customer expectations. Das et al. (2018) explored the barriers of innovation in banks. One of the key barriers was lack research on ways to exploit new ideas which are central in co-creation. Hence, co-creation of value in the banking sector represents an important topic for research (Mainardes et al. 2017). Unfortunately the area still lack of support in the literature. The recent literature explore mobile payment service (Hsiao 2019) which concentrate on service of payment and not the value creation as integrated perspective.

The concept of co-creation has manifested in various terms such as co-production (Auh et al. 2007, Etgar 2008, Lehrer et al. 2012), open innovation, and prosumption. In an integrative view of co-creation, these terms are inseparable and identified as upstream and downstream cocreation activities connected by platforms (Leclercq et al. 2016, Vernette and Hamdi 2013). Upstream co-creation or provider sphere (Gronroos and Voima 2013) deals with idea development and concept prototyping, whilst downstream co-creation or customer sphere (Gronroos and Voima 2013) focuses on providing extraordinary consumption experiences to customers. Gronroos and Voima (2013) added a joint sphere in which the upstream and downstream activities align in co-creation between providers and customers.

Despite efforts to advance the value co-creation theory, a meta-analysis of co-creation by Galvagno and Dalli (2014) and the study by Leclercq et al. (2016) have revealed the lack of an integrative framework for co-creation measurement. This has been one of the gaps pointed out by Jaakkola et al. (2015) and Oertzen et al. (2018), also recently Corsaro (2019). The numerous contributions to the advancement of co-creation have not been backed up by an integrated measurement of the theory. Several studies have tried to overcome this issue. Yi and Gong (2013) modelled two-tier value co-creation, supported by the two dimensions of customer participation and citizenship behavior. Mainardes et al. (2017) developed a scale measurement adopting DART (dialogue, access, risk assessment, and transparency) variables from Prahalad and Ramaswamy (2004). Merz et al. (2018) developed a customer co-creation value scale using the dimensions of customer motivation and customerowned resources. However, these measurements are suitable only for direct interaction between companies and customers (Prahalad and Ramaswamy 2004), not the indirect moments where customers still act as an independent value creator. Hence, a gap still remains in providing an integrative concept of co-creation that encompasses direct and indirect interactions with the customers (Gronroos and Voima 2013). Achieving this would close the gap between theory and practice and help explain the effect of co-creation on customers' commitment and loyalty (Chan et al. 2010, Galvagno and Dalli 2014).
The advancement of the theory of S-D logic requires a middle-range theory as a bridge between grand theory and practice, based on empirical evidence (Vargo and Lusch 2017). One of the important concepts here is value co-creation. The current study aims to fill this gap by developing and testing a measurement model for integrated value cocreation (IVC) in the service industry. It begins by utilizing the three spheres framework of value co-creation from the work of Grönroos and Voima (2013), developing these spheres into measurement tools for IVC. Each measurement is derived from the exact examples of each sphere's conceptualization, following Grönroos and Voima (2013). The derivation of the scale's properties from the literature review, creation of the item pool, and construct testing follow the work of Clark and Watson (1995). The second objective of the study is to validate the relationship of value co-creation with affective commitment. It has been argued that testing the IVC construct in relation to customers' commitment is crucial due to the unconformity found in the literature on the outcomes of co-creation (Chan et al. 2010).

\section{Literature review}

\section{Co-creation in service industry}

In the limited literature attempting to provide an integrative framework for understanding value co-creation, the work of Grönroos and Voima (2013) and Oertzen et al. (2018) are key. Grönroos and Voima (2013) identified three spheres of value creation in the service industry: provider sphere; joint sphere; and customer sphere. The three spheres represent the phases of value creation that involve all stakeholders in the company (see Figure 1).

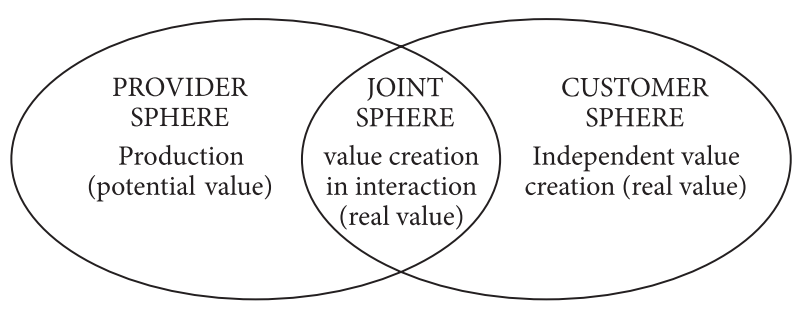

Figure 1. Value creation spheres (Gronroos and Voima 2013)

In the provider sphere, the provider performs production processes to provide resources ready to be used in the customers' value creation. Obviously, the provider of a service takes a dominant role as value facilitator with all their resources. The output presents a range of potential value that can be rendered by the customer in the next stage or sphere. In the service industry, preparation of production has already included some aspect of customers' involvement. The provider can deliver value directly through the preparation of their personnel or indirectly by providing access to technology platforms through which customers 
can experience some services (Martovoy and Santos 2012). Similarly, Merrilees et al. (2017) found that staff can cocreate directly when servicing the customers and indirectly through improved business process. Thus, the corresponding measures of the provider sphere will be directed toward measuring the provider's effort to create value experience opportunities by providing service personnel and (or) technological platforms or other business processes to capture the potential value creation.

In the joint sphere, customers participate in a joint production process and create a real value. Thus, the real value can only be created through a direct interaction between customer and service provider. The interaction can happen using provider resources or customer resources. This translates to passive and active direct interaction between customer and service provider. The measurements should therefore recognize the types of interaction to be included in the scale.

The third sphere is the customer sphere. It is an area where the customer independently acts as a value creator outside of interaction with the provider. The role of the customer as the value creator is dominant in this part. Again, there are two types of independent value creation. The first involves the customer remembering interaction with the provider and the second involves the customer discussing the service provider within their social environment. Both types should be considered in the scale measurement in this phase, as customers are trying to increase their knowledge about the product after direct interaction with the service provider.

The second framework for integration of value co-creation was developed by Oertzen et al. (2018). The concept emphasizes involvement, engagement, and participation as prerequisites for the co-creation of services. It also, however, argues for a slightly different understanding of the co-creation of value and the co-creation of services, which limits the scope of integrative value co-creation that the present research is trying to develop. Since the current research is attempting is to develop an integrative concept that accommodates all interactions across the process and to include all possible types of interaction (direct and indirect, active and passive), the study chooses to use the framework of Gronroos and Voima (2013) as a basis for developing the measurement model. It is argued that the three spheres can provide a general yet flexible base for understanding the integrative nature of value co-creation in services.

\section{Value co-creation consequences}

Value co-creation has been found to positively affect help intention, feedback intention, willingness to pay a premium price, purchase intention, positive word-of-mouth, social media behavior, and actual co-creation behavior in a social media context (Merz et al. 2018). However, a study by Chan et al. (2010) found different results. Investigating the employee perspective in value co-creation, the study found that co-creation increased job stress and hampered satisfaction in the context of financial services. In the long term, employee dissatisfaction might also affect their performance and customers' affective commitment. This unconformity in financial services industry warrants for further investigation.

Value co-creation has been suggested to have associations with other constructs, in this case affective commitment. Affective commitment is defined as the desire to maintain a relationship that has value for the customer (Morgan and Hunt 1994). It is the customer's emotional attachment to a brand or organization (Allen and Meyer 1990). Affective commitment has been reported to have an association with increased involvement in co-production (Auh et al. 2007). This study suggested that value cocreation results in increased engagement that will have a positive impact on customers' emotional commitment. The following hypothesis is therefore proposed:

H1. Value co-creation has a positive impact on affective commitment.

\section{Methodology}

The authors conducted a quantitative survey to determine the measurement scale and confirm relationships within the model. The target respondents were bank customers aged 20 years old or over who currently reside in Indonesia. The questions for IVC were developed using value sphere framework of Gronroos and Voima (2013). This resulted in nine initial indicators to measure value co-creation. The conceptualization of the three spheres was chosen as it is one of the few conceptual works that represent value co-creation from an integrative perspective. The study used three indicators for each sphere. The provider sphere represents a process of creating value between company and its service suppliers with minimal customer involvement, an example of which would be the availability of a platform for co-creation. The current study translated this sphere into: the availability of co-creation opportunities in general; the availability of technology; and service personnel. The joint sphere involves customers jointly creating value with the service providers. The indicators for this sphere were: simple encounters; the exchange of resources (data, information, money, work, time); and collaboration practices in which both parties conduct activities (Payne et al. 2008). The customer sphere includes value co-creation that customers undertake independently or with other customers, with minimal involvement of the company. The indicators for this sphere were: increasing knowledge about the service; thinking about the interactions; and discussing with other customers.

The affective commitment scale adopted Allen and Meyer's (1990) four indicators. The six indicators for attitudinal loyalty were adopted from Boulding et al. (1993), which 
have been found to be robust indicators in previous research. All statements were measured using a five-point Likert scale from 1 for "strongly disagree" to 5 for "strongly agree."

The data gathered were processed in two stages. The first stage involved exploratory factor analysis (EFA) using SPSS to confirm the number of factor solutions and the suitability of the indicator items. The second stage involved structural equation modeling (SEM), using SmartPLS version 3.2.6 software, which was run based on partial least squares (PLS). One of the differences between SmartPLS, which employs PLSbased SEM and LISREL (which employs covariance-based $\mathrm{SEM})$, lies in the process of generating confirmatory factor analysis (CFA). In covariance-based SEM, the CFA needs to be confirmed first before moving to the structural model, whereas in PLS-SEM, the analysis begins with a structural (inner) model with CFA results being part of the calculations of the outer model (Astrachan et al. 2014). The analysis in section 4 follows these two stages, starting with the EFA results, followed by the SEM results, examining the outer model, inner model, and hypotheses testing.

\section{Result and discussion}

The authors obtained 308 respondents. A slight majority of respondents were males (51.9\% or 160 respondents). The largest age group was adults aged $30-35$ years old $(34.09 \%$ or 105 respondents) and the majority of respondents had middle and upper socio-economic status (65.91\%). Mostly educated and finished undergraduate degree $(42.21 \%$ or 130 respondents). The data were processed with SPSS for Exploratory Factor Analysis to reduce the number of dimensions and tested for reliability. The results were presented in two parts, first the EFA and then the Integrated Value Co-Creation (IVC) result on relationship to Affective Commitment (AC).

\section{Exploratory factor analysis}

As the variable of IVC has been taken for this research from the literature review, justification is needed to account for the indicators as one variable. For this purpose, the study began with an EFA. First, the Kaiser-Meyer-Olkin (KMO) measure of sampling adequacy and Bartlett's test of sphericity were employed to determine whether factor

Table 1. Results of the Kaiser-Meyer-Olkin (KMO) measure of sampling adequacy and Bartlett's test of sphericity

\begin{tabular}{|l|c|}
\hline KMO measure of sampling adequacy & 0.944 \\
\hline Bartlett's test of sphericity & \\
\hline Approx. chi-square & 2680.334 \\
\hline df & 78 \\
\hline Sig. & 0.000 \\
\hline
\end{tabular}

analysis was suitable for the data (Table 1). The KMO result measuring sampling adequacy was 0.944 , which is above the commonly recommended value of 0.6. and Bartlett's test of sphericity was significant $\left(\chi^{2(78)}=2680, p<0.05\right)$. Given the indicators, factor analysis was deemed suitable to be conducted for all items.

The process continued with principal component analysis (PCA) to determine the number of factor solutions for the model based on the eigenvalues criteria of $>1$. Initial eigenvalues indicated that there are two factors cumulatively contribute $66.66 \%$ of the variance. Therefore, it was confirmed that the model has a two-factor solution. This result aligns with the two constructs to be analyzed, namely integrated value co-creation (IVC) and affective commitment (AC).

The next step utilized a factor extraction approach to seek the optimum number of items that accounted for one common factor or variable. The criterion used was to keep items that have loadings above 0.5 for each variable and to retain a minimum of three items for each variable. Principal axis factoring with Varimax rotation was employed, with the number factor fixed to three. The results loaded items for IVC and AF into separate factors, the results of which are shown in Table 2.

From these results, all nine items for IVC accounted for one factor, with loadings for all items above 0.5. Similarly, all four items for AF also grouped as one construct, with factor loadings above the criteria of 0.5. Therefore, it was confirmed that the indicators represented each construct as single variable. All items were suitable for further processing

Table 2. Rotated factor matrix

\begin{tabular}{|c|c|c|}
\hline \multirow{2}{*}{} & \multicolumn{2}{|c|}{ Factor } \\
\hline & 1 & 2 \\
\hline CP & 0.645 & \\
\hline CP1 & 0.653 & \\
\hline CP2 & 0.681 & \\
\hline CE & 0.596 & \\
\hline CE1 & 0.747 & \\
\hline CE2 & 0.591 & \\
\hline CC & 0.709 & \\
\hline CC1 & 0.767 & 0.777 \\
\hline CC2 & 0.700 & 0.747 \\
\hline AF1 & & 0.650 \\
\hline AF2 & & 0.674 \\
\hline AF3 & & \\
\hline AF4 & & \\
\hline
\end{tabular}

Note: Extraction method: principal axis factoring. Rotation method: Varimax with Kaiser normalization. 
via CFA, followed by SEM. The current study employed PLS-SEM, using SmartPLS, resulting in outer model analysis and inner model analysis.

\section{Reliability and validity analysis}

Evaluation of the variables were conducted by checking internal consistency reliability, indicator reliability, and convergent and discriminant validity of the indicators against several criteria. Following Hair, Hult, Ringle, and Sarstedt (2014), the study tested the reflective measurement model for reliability using Cronbach's alpha and composite reliability threshold criterion of 0.7 . The study also checked the validity with average variance extracted (AVE); an AVE higher than 0.5 indicates an acceptable level of validity.

The measurement model showed that all value co-creation indicators passed the reliability and validity criteria. The highest indicator loading was 0.818 and the lowest was 0.709. The construct's Cronbach alpha was 0.927 and its AVE value was 0.633 . Thus, all nine indicators for value cocreation were found to be reliable and valid for the set of data tested. A similar result was also found for affective commitment (Cronbach's alpha: 0.869; AVE: 0.721) and attitudinal loyalty (Cronbach's alpha: 0.876; AVE: 0.617). All indicators, consisting of four indicators for affective commitment and six indicators for attitudinal loyalty, passed the loading criteria and were proven to be reliable and valid. The result implies that all of the indicators were valid measures for the constructs (see Table 3).

\section{Hypothesis result}

Hypothesis assessment started with examination of the path coefficient with a critical value 1.96 (significance level $=5 \%$ ), followed by path analyses assessing the coefficient of determination (R-squared values). The path coefficient from value co-creation to affective commitment (H1) showed a coefficient value of 0.738 with a $t$-value of 18.931. The result implies that value co-creation has a positive and significant impact on affective commitment. The finding supports previous literature that has found that involvement in co-production associates positively with affective commitment (Auh et al. 2007). Co-production was translated in this research with indicators measuring the opportunity of co-creation, the availability of a technology platform, and the availability of personnel assistance.

Table 3. Outer model

\begin{tabular}{|c|c|c|c|c|c|c|}
\hline Indicators & $\begin{array}{l}\text { Mean } \\
\text { value }\end{array}$ & $\begin{array}{l}\text { Standard } \\
\text { deviation }\end{array}$ & $\begin{array}{l}\text { Loading } \\
\text { coefficient }\end{array}$ & $\begin{array}{l}\text { Cronbach's } \\
\text { alpha }\end{array}$ & $\begin{array}{l}\text { Composite } \\
\text { Reliability }\end{array}$ & $\begin{array}{l}\text { Average } \\
\text { variance } \\
\text { extracted }\end{array}$ \\
\hline \multicolumn{4}{|l|}{ Co-creation } & \multirow{10}{*}{0.927} & \multirow{10}{*}{0.939} & \multirow{10}{*}{0.633} \\
\hline $\begin{array}{l}\text { CP. This bank provides an opportunity for its } \\
\text { customers to create services that meet their needs }\end{array}$ & 3.72 & 0.779 & 0.81 & & & \\
\hline $\begin{array}{l}\text { CP1. This bank provides technology for its } \\
\text { customers to create services that meet their needs }\end{array}$ & 3.96 & 0.739 & 0.842 & & & \\
\hline $\begin{array}{l}\text { CP2. This bank provides bank personnel to assist its } \\
\text { customers in creating services that meet their needs }\end{array}$ & 3.85 & 0.757 & 0.82 & & & \\
\hline $\begin{array}{l}\text { CE. I work together with banks to process the } \\
\text { services }\end{array}$ & 3.7 & 0.787 & 0.776 & & & \\
\hline $\begin{array}{l}\text { CE1. I provide data that the bank needs for the } \\
\text { services I want }\end{array}$ & 3.86 & 0.759 & 0.806 & & & \\
\hline $\begin{array}{l}\text { CE2. I am actively present in the process of my } \\
\text { banking services }\end{array}$ & 3.55 & 0.803 & 0.774 & & & \\
\hline $\begin{array}{l}\text { CC. I increase my knowledge about this bank's } \\
\text { services from various channels }\end{array}$ & 3.72 & 0.795 & 0.8 & & & \\
\hline CC1. I remember the interaction with this bank & 3.74 & 0.778 & 0.734 & & & \\
\hline $\begin{array}{l}\text { CC2. I talked about this bank service with my } \\
\text { social environment }\end{array}$ & 3.68 & 0.802 & 0.793 & & & \\
\hline Affective commitment & & & & \multirow{5}{*}{0.869} & \multirow{5}{*}{0.911} & \multirow{5}{*}{0.721} \\
\hline $\begin{array}{l}\text { AF1. I feel as part of a large family of bank } \\
\text { customers }\end{array}$ & 3.56 & 0.862 & 0.899 & & & \\
\hline AF2. This bank has a special meaning for me & 3.54 & 0.87 & 0.859 & & & \\
\hline AF3. I feel emotionally bound to this bank & 3.31 & 0.905 & 0.765 & & & \\
\hline $\begin{array}{l}\text { AF4. I feel a sense of togetherness and mutual need } \\
\text { with this bank }\end{array}$ & 3.63 & 0.822 & 0.867 & & & \\
\hline
\end{tabular}


The indicators for IVC showed that providing customers with technology (CP1) had the highest score of agreement among IVC measures (M: 3.96; SD: 0.739), Thus, the result of the current study supports hypothesis which stated a positive and significant relationship between the constructs. With an R-squared values of 0.544 , the results of the model implying that value co-creation significantly predicted affective commitment variance by $54.4 \%$, with the remainder predicted by other factors.

\section{Conclusions}

The present study began with a proposal to develop an integrative measure for value co-creation. A gap in the literature was highlighted regarding the lack of a measurement tool that encompasses all spheres of value co-creation, namely the production sphere, the joint sphere and the customer sphere. In addition, a need was highlighted to investigate the impact of value co-creation in the service industry. In order to fill the gap, the present research aimed to develop a scale measuring IVC to assess value co-creation in Gronroos and Voima's (2013) three spheres of value creation and tested the proposed model in a survey of 308 respondents who were customers in the banking industry. The data were gathered and analyzed against four hypotheses representing a model of the relationship between IVC and AC from the customers' perspective. All hypotheses were supported, providing important theoretical and managerial insights. The first concerns the development of a new set of indicators for value co-creation, while the second concerns the validation of the impact of value co-creation on loyalty constructs.

\section{Theoretical contributions}

The results contribute theoretically by providing an integrative yet simple measurement tool for value co-creation in the service industry. The proposed model captures the value co-creation concept as part of a wider perspective of business spheres, while also adding depth to the conceptualization of co-creation by including different types of interactions. The study provides empirical evidence of the shift from traditional service delivery experiences to exchanges of experience as suggested by Ramaswamy and Ozcan (2018). This experience is developed through indirect and direct interactions, including the passive and active involvement of customers. This shift is reflected in a parsimonious scale to measure value co-creation. The scale was tested and found to be reliable and valid for use in future studies. The results also supported the hypotheses that IVC has predictive ability for AC. The present study demonstrates that the measurement of IVC has a potential for long-term contributions in creating commitment which is a precursor for loyalty.

\section{Managerial contributions}

The findings can help managers to assess the co-creation process in their organization in two ways. First, the indicators can act as evaluation tools for the co-creation process. By utilizing the measurements, managers can plan and evaluate co-creation processes within a framework covering all three spheres of value creation. They can identify which spheres of value co-creation can be improved and how the value of co-creation can be developed further. Second, the model demonstrates that co-creation requires contact not only at customer contact points but also contact before and after. The findings also imply that co-creation can result in emotional bonding, which is a valid predictor of loyalty. Therefore, the emotional side of every phase of the process should be designed carefully. Finally, managers can use the simple measurement of value co-creation as a strategic tool in their business units to determine which parts of the business, in terms of service, require more technological solutions and which require a more human touch, adjusting their strategies to the target segment accordingly.

\section{Limitations and further research}

The present study has limitations that reveal directions for future investigation. First, it was conducted in homogeneous environment, comprising bank customers only. Thus, the generalizability to other contexts is limited and should be further assessed in other industries. Aquilani et al. (2018) going toward this direction by merging the framework of sustainability and co-creation in bio-economy. Second, the current study needs to be triangulated in an explorative manner, using a qualitative approach to provide richer insights and possibly define typologies of value co-creation. Corsaro (2019) pointed out there are value appropriation, value measuring, value representation and value communication which have not been addressed by current study. The current model can also be expanded to include antecedents or drivers of value co-creation. Other constructs, such as behavioral loyalty, can be investigated further in relation to the model.

\section{Funding}

This research did not receive any specific grant from funding agencies in the public, commercial, or not-for-profit sectors.

\section{References}

Astrachan CB, Patel, VK, Wanzenried G (2014) A comparative study of CB-SEM and PLS-SEM for theory development in family firm research. Journal of Family Business Strategy 5 (1): 116-128. https://doi.org/10.1016/j.jfbs.2013.12.002

Allen NJ, Meyer JP (1990) The measurement and antecedents of affective, continuance and normative commitment to the 
organization. Journal of Occupational Psychology 63 (1): 1-18. https://doi.org/10.1111/j.2044-8325.1990.tb00506.x

Auh S, Bell SJ, McLeod CS, Shih E (2007) Co-production and customer loyalty in financial services. Journal of Retailing 83 (3): 359-370. https://doi.org/10.1016/j.jretai.2007.03.001

Aquilani B, Silvestri C, Ioppolo G, Ruggieri A (2018) The challenging transition to bio-economies: Towards a new framework integrating corporate sustainability and value co-creation. Journal of Cleaner Production 172: 4001-4009. https://doi.org/10.1016/j.jclepro.2017.03.153

Boulding W, Kalra A, Staelin R, Zeithaml VA (1993) A dynamic process model of service quality: from expectations to behavioral intentions. Journal of Marketing Research 30 (1): 7-27. https://doi.org/10.1177/002224379303000102

Clark LA, Watson D (1995) Constructing validity: basic issues in objective scale development. Psychological Assessment 7 (3): 309. https://doi.org/10.1037//1040-3590.7.3.309

Comfort N (2019) Banks announced almost 50,000 job cuts this year, led by Europe https://www.bloomberg.com/news/ articles/2019-08-15/banks-announced-almost-50-000-jobcuts-this-year-led-by-europe

Corsaro D (2019) Capturing the broader picture of value co-creation management. European Management Journal 37 (1): 99-116. https://doi.org/10.1016/j.emj.2018.07.007

Das P, Verburg R, Verbraeck A, Bonebakker L (2018) Barriers to innovation within large financial services firms: An in-depth study into disruptive and radical innovation projects at a bank. European Journal of Innovation Management 21 (1): 96-112. https://doi.org/10.1108/EJIM-03-2017-0028

Etgar M (2008) A descriptive model of the consumer co-production process. Journal of the Academy of Marketing Science 36 (1): 97-108. https://doi.org/10.1007/s11747-007-0061-1

Galvagno M, Dalli D (2014) Theory of value co-creation: a systematic literature review. Managing Service Quality 24 (6): 643-683. https://doi.org/10.1108/MSQ-09-2013-0187

Grönroos C, Voima P (2013) Critical service logic: making sense of value creation and co-creation. Journal of the Academy of Marketing Science 41 (2): 133-150. https://doi.org/10.1007/s11747-012-0308-3

Hsiao MH (2019) Mobile payment services as a facilitator of value co-creation: A conceptual framework. The Journal of High Technology Management Research 100353. https://doi.org/10.1016/j.hitech.2019.100353

Jaakkola E, Helkkula A, Aarikka-Stenroos L (2015) Service experience co-creation: conceptualization, implications, and future research directions. Journal of Service Management 26 (2): 182-205. https://doi.org/10.1108/JOSM-12-2014-0323

Jimenez A (2019) Is the banking industry experiencing its own "Kodak Moment"? https://thefinancialbrand.com/73382/banking-fintech-moment-kodak-blockbuster-borders-uber-trends/

Leclercq T, Hammedi W, Poncin I (2016) Ten years of value cocreation: An integrative review. Recherche et Applications en Marketing 31 (3): 26-60. https://doi.org/10.1177/2051570716650172

Lehrer M, Ordanini A, DeFillippi R et al. (2012) Challenging the orthodoxy of value co-creation theory: A contingent view of co-production in design-intensive business services. European Management Journal 30 (6): 499-509.

https://doi.org/10.1016/j.emj.2012.07.006
Mainardes EW, Teixeira A, Romano PCDS (2017) Determinants of co-creation in banking services. International Journal of Bank Marketing 35 (2): 187-204. https://doi.org/10.1108/IJBM-10-2015-0165

Martovoy A, Dos Santos J (2012) Co-creation and co-profiting in financial services. International Journal of Entrepreneurship and Innovation Management 16 (1-2): 114-135. https://doi.org/10.1504/IJEIM.2012.050446

Merrilees B, Miller D, Yakimova R (2017) The role of staff engagement in facilitating staff-led value co-creation. Journal of Service Management 28 (2): 250-264. https://doi.org/10.1108/JOSM-10-2015-0326

Merz MA, Zarantonello L, Grappi S (2018) How valuable are your customers in the brand value co-creation process? The development of a Customer Co-Creation Value (CCCV) scale. Journal of Business Research 82: 79-89. https://doi.org/10.1016/j.jbusres.2017.08.018

Morgan RM, Hunt SD (1994) The commitment-trust theory of relationship marketing. The Journal of Marketing, 20-38. https://doi.org/10.2307/1252308

Oliveira P, von Hippel E (2011) Users as service innovators: The case of banking services. Research Policy 40 (6): 806-818. https://doi.org/10.1016/j.respol.2011.03.009

Oertzen AS, Odekerken-Schröder G, Brax SA, Mager B (2018) Co-creating services - conceptual clarification, forms and outcomes. Journal of Service Management 29 (4): 641-679. https://doi.org/10.1108/JOSM-03-2017-0067

Payne AF, Storbacka K, Frow P (2008) Managing the co-creation of value. Journal of the Academy of Marketing Science 36 (1): 83-96. https://doi.org/10.1007/s11747-007-0070-0

Prahalad CK, Ramaswamy V (2004) Co-creation experiences: The next practice in value creation. Journal of Interactive Marketing 18 (3): 5-14. https://doi.org/10.1002/dir.20015

Ramaswamy V, Ozcan K (2018) What is co-creation? An interactional creation framework and its implications for value creation. Journal of Business Research 84: 196-205. https://doi.org/10.1016/j.jbusres.2017.11.027

Saarijärvi H, Kannan PK, Kuusela H (2013) Value co-creation: theoretical approaches and practical implications. European Business Review 25 (1): 6-19. https://doi.org/10.1108/09555341311287718

Sarkar S, Banerjee S (2019) Brand co-creation through triadic stakeholder participation. European Business Review 31 (5): 585-609. https://doi.org/10.1108/EBR-04-2018-0079

Vargo SL, Lusch RF (2004) Evolving to a new dominant logic for marketing. Journal of Marketing 68: 1-17. https://doi.org/10.1509/jmkg.68.1.1.24036

Vargo SL, Lusch RF (2008) Service-dominant logic: continuing the evolution. Journal of the Academy of Marketing Science 36 (1): 1-10. https://doi.org/10.1007/s11747-007-0069-6

Vargo SL, Lusch RF (2017) Service-dominant logic for 2025. International Journal of Research in Marketing 34 (1): 46-67. https://doi.org/10.1016/j.ijresmar.2016.11.001

Yi Y, Gong T (2013) Customer value co-creation behavior: Scale development and validation. Journal of Business Research 66 (9): $1279-1284$. https://doi.org/10.1016/j.jbusres.2012.02.026 